\title{
Global Trends in Rural People Livelihood Practice of Raft Culture of Red Seaweed, Kappaphycus alvarezii in Gujarat, India
}

\author{
Nakul Bhatt A. ${ }^{1^{*}}$, B. K. Sharma ${ }^{2}$, D. T. Vaghela ${ }^{3}$ and Divu D. ${ }^{4}$ \\ ${ }^{184}$ Dept. of mariculture, CMFRI, Veraval, Gujarat (362 265), India \\ ${ }^{2}$ Dept. of Aquaculture, College of fisheries, MPUAT, Udaipur, Rajasthan (313 001), India \\ ${ }^{3}$ Dept. FRM, College of fisheries, JAU, Verval, Gujarat (362 001), India
}

\section{Corresponding Author}

Nakul Bhatt A.

e-mail: nakulbhatt66@gmail.com

\author{
Article History \\ Article ID: $3 \mathrm{C0668}$ \\ Received in $26^{\text {th }}$ October, 2017 \\ Received in revised form $20^{\text {th }}$ April, 2018 \\ Accepted in final form $28^{\text {th }}$ May, 2018
}

\begin{abstract}
India is rich in biodiversity, especially of marine biodiversity. Marine biodiversity includes both flora and fauna. There are 20,000 species of seaweed worldwide, half of them are economically important and 280 are edible. Kappaphycus is a red alga belonging to Rhodophyceae. It grows profusely in the sea where the bottom is sandy and salinity ranges from 29-34 ppt. it requires only sunlight, transparent seawater with mild wave action for replenishing bottom nutrients. It has also been proved that Kappaphycus grow $>10$ times in open sea where wave action is fairly high. Kappaphycus is carrageen yielding res algae cultivated amount of south pacific countries. In Gujarat, Kappaphycus grows to throw vegetative propagation using floating rafts. An experimental on Kappaphycus cultivation at five different cultivation sites wiz, Okha, Dwarka, Porbandar, Chorwad and Veraval. The growth was major at an interval of 15 days. The final weights were major at $45^{\text {th }}$ to $60^{\text {th }}$ days. It was observed that maximum vegetative growths were exhibited by Okha center wild lowest growth was observed in Porbandar. The DGR (\%) was found to be maximum at Okha site $61.35 \mathrm{~kg}, 54.75 \mathrm{~kg}$ and $33.15 \mathrm{~kg}$ wild to lowest DGR (\%) was observed at Porbandar $33.15 \mathrm{~kg}, 22.2$ $\mathrm{kg}$ and $20.2 \mathrm{~kg}$. Further, it was significantly correlated to salinity at Dwarka, Okha while at Porbandar and Chorwad, Veraval the same was significantly correlated to nitrate and seawater temperature. Based on this study, commercial cultivation at these localities is quite feasible.
\end{abstract}

Keywords: Cultivation, five sites, Kappaphycus alvarezii (red algae), seaweed

\section{Introduction}

Commercial cultivation of Kappaphycus was started in the Philippines in 1960's and since then many countries like China, Japan, Indonesia, Hawaii and South Africa have been cultivating Kappaphycus on a large scale (C.M.F.R.I, 2015). In India, Kappaphycus alvarezii (Doty) Doty ex P. C. Silva cultivation was initiated in mid-1990 at Okha, Gujarat on Northwest coast and later in Mandapam, Tamil Nadu on Southeast coast (Chandrasekaran et al., 2008). Kappaphycus alvareziiis economically important tropical red seaweed with a high demand worldwide for its cell wall polysaccharide, carrageenan (Mantri et al., 2017). This polysaccharide is used as an additive particularly as gelling, thickening and stabilizing agent in foodstuffs like frozen desserts, chocolate milk, cottage cheese, jellies, sauces etc. (Makwana, 2011; Monica et al., 2016) . It is also used as an additive in cosmetics and pharmaceutical formulations (Ghosh et al., 2014; Naguit et al., 2009). D- type carbohydrates like D-galactose-4-sulfate and 3,6-anhydro-D-galactose-2-sulfate are the main components of carrageenan and have a high potential for fermentation. This alga also acts as a raw material for biofertilizer and bioethanol production (Bixler and Porse, 2011).

Several marine algae have been reported to possess medicinal value and traditionally used in many countries. Carrageenan is useful in ulcer therapy and alginate prolong the period of activity of certain drugs (De Goes and Reis, 2011; Necas and Bartosikova, 2013). Seaweeds grow in many parts of the east and west coasts, but Tamilnadu coast is a paradise for seaweeds and no other coastline of our country can be compared with Tamilnadu coast in diversity and density of seaweed, but now Gujarat state is on momentum toward seaweed cultivation and harvesting natural stock to fulfill the required industrial raw demand.

The present study deals with the cultivation of Kappaphycus at various places of Gujarat coast. Since Gujarat has long coast line of about $1600 \mathrm{~km}$ which could be utilized for cultivation of the most efficient and fast-growing seaweed like $K$. alvarezii. This seaweed can produce alarge quantity of biomass within a short period of time and the biomass can be harvested several times in a year. The main objective of the work is to cultivate Kappaphycus in the coastal region of Gujarat and creating awareness about the benefits of seaweed cultivation among 
the people. Biomass produced through cultivation will fulfill the growing need of the industries. More importantly, it will improve the socio-economic status of the native people of the coastal region.

\section{Materials and Methods}

The experiment was conducted during three seasons at five different coastal villages of the Gujarat region from November 2017 to October 2017. (summer, winter and monsoon, Table $1)$. K. alvarezii seed was selected for the experiment. $K$. alvarezii (around $58 \mathrm{~kg}$ ) was procured from Okha (Research station, JAU, Gujarat, India). Plastic ropes of $3 \mathrm{~mm}$ thickness were used as a bit, where ten individual bunches of germplasm were tied by means of braider twine termed a loop. Loops of

\begin{tabular}{|c|c|c|c|c|c|c|c|}
\hline \multirow{2}{*}{$\begin{array}{l}\text { Sl. } \\
\text { No. }\end{array}$} & \multicolumn{3}{|c|}{ Winter } & \multicolumn{2}{|c|}{ Summer } & \multicolumn{2}{|c|}{ Monsoon } \\
\hline & Location & $\begin{array}{c}\text { Raft place on } \\
\text { dated }\end{array}$ & $\begin{array}{c}\text { Harvested } \\
\text { date }\end{array}$ & $\begin{array}{c}\text { Raft place on } \\
\text { dated }\end{array}$ & Harvested date & $\begin{array}{c}\text { Raft place on } \\
\text { dated }\end{array}$ & Harvested date \\
\hline 1. & Okha & $15-11-2016$ & $2-2-2017$ & $5-2-2017$ & $8-5-2017$ & $22-6-2017$ & $15-10-2017$ \\
\hline 2. & Dwarka & 17-11-2016 & 2-2-2017 & $5-2-2017$ & $8-5-2017$ & $22-6-2017$ & $15-10-2017$ \\
\hline 3. & Porbandar & 17-11-2016 & $3-2-2017$ & $5-2-2017$ & $9-5-2017$ & $24-6-2017$ & $17-10-2017$ \\
\hline 4. & Chorwad & 18-11-2016 & 3-2-2017 & $7-2-2017$ & $11-5-2017$ & 27-6-2017 & 19-10-2017 \\
\hline 5. & Veraval & 19-11-2016 & $3-2-2017$ & $7-2-2017$ & $11-5-2017$ & 27-6-2017 & 19-10-2017 \\
\hline
\end{tabular}

about $2 \mathrm{~cm}$ were secured by one end through the line plaits at intervals of about $15-20 \mathrm{~cm}$. The other end of the loop was left loose. During planting the line was pushed through the loop, propagate inserted and the line snug pulled to secure the germplasm (Renuga et al., 2013). There were five main ropes in a raft holding ten germplasm. The growth of the $K$. alvareziiwas measured by weighing near the shore.

\subsection{Experimental setup}

Four good floating 12 feet bamboo poles for mainframes and four 6 feet bamboo poles for additional frames were selected for construction of a bamboo raft with the help of ropes. The interior part of the main frame was $3 \times 3 \mathrm{~m}^{2}$ in size. Fish nets were tied under the raft to avoid the grazing. Around $11.0 \mathrm{~kg}$ of $K$. alvarezii germplasm was utilized at each selected site (5.5 kg per single floating raft). Approximately $5.5 \mathrm{~kg}$ of $K$. alvareziiwere planted in each raft, total $5.5 \times 2=11.0 \mathrm{~kg}(1 \times 1$ $\mathrm{m}^{2}$ ). Each raft had a total of five ropes of $3 \mathrm{~mm}$ thickness and the ropes consisted of five loops. The distance between the loops was $20-22 \mathrm{~cm}$. The 25 loops in the raft were inserted with $100 \mathrm{~g}$ K.alvarezii germplasm. A similar procedure was used for all the rafts at all five stations. $K$. alvarezii growth was calculated after totally 45-60 days culture periods for each season (summer, winter and monsoon).

\subsection{Statistical analysis}

Daily Growth Rate (DGR) in percent study was calculated by using following formula given by Dawes et al., 1994.

$$
\text { DGR \% }=\frac{\ln \left(W_{f}-W_{0}\right)}{t} \times 100
$$

$W_{f}$ is the final fresh weight $(g)$ at the day,

$\mathrm{W}_{0}$ is the initial fresh weight $(\mathrm{g})$,

$t$ is the number of culture days

The physic-chemical data recorded for these stations were used in the subsequent statistical analyses. In the present study viz., water temperature, salinity, concentrations of nitrate, and total phosphates within each site including surface and bottom samples were analyzed separately by the Pearson product-movement correlation coefficient (Khambhaty et al., 2012; Thirumaran and Anantharaman, 2009).

\section{Results and Discussion}

The cultivation of Kappaphycus alvarezii was carried out for three seasons during the month of November (2016) to October (2017). The crop was ready to harvest after 45-60 days of planting (Figure 1). Average yield per sites in per season $\left(3 \times 3 \mathrm{~m}^{2}\right)$ was $61.35 \pm 1.63 \mathrm{~kg}$ (Summer), $54.75 \pm 0.78 \mathrm{~kg}$ (Winter), $33.15 \pm 0.92 \mathrm{~kg}$ (Monsoon). The maximum average was recorded in Okha (summer, winter and monsoon seasons

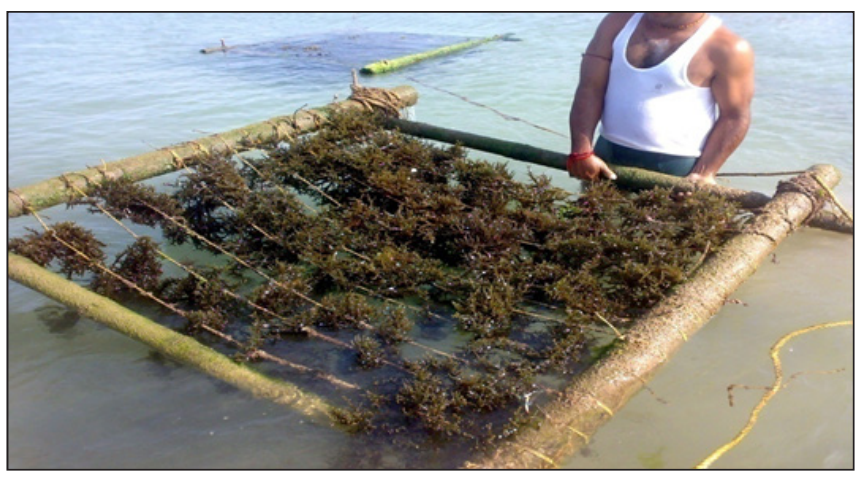

Figure 1: Raft culture of Kappaphycus alvarezii during harvesting

$61.35 \mathrm{~kg}, 54.75 \mathrm{~kg}$ and $33.15 \mathrm{~kg}$ in 45 days. In Chorwad was recorded next with $59.65 \mathrm{~kg}, 52.15 \mathrm{~kg}, 30.25 \mathrm{~kg}$ and the minimum average growth was recorded $33.15 \mathrm{~kg}, 22.2 \mathrm{~kg}$ and $20.2 \mathrm{~kg}$ in all three season in Porbandar. Medium growth was recorded at Veraval in all seasons (20.64, 15.48 and 9.64 kg) seen in Table 2.

The water quality parameters salinity and temperature 


\begin{tabular}{|c|c|c|c|c|c|c|c|c|c|c|}
\hline \multirow[t]{3}{*}{ Location } & & \multirow{2}{*}{\multicolumn{3}{|c|}{$\begin{array}{c}\text { Mean of raft in kg } \\
\text { Summer }\end{array}$}} & \multirow{2}{*}{\multicolumn{3}{|c|}{$\begin{array}{c}\text { Mean of raft in kg } \\
\text { Winter }\end{array}$}} & \multirow{2}{*}{\multicolumn{3}{|c|}{$\begin{array}{c}\text { Mean of raft in kg } \\
\text { Monsoon }\end{array}$}} \\
\hline & & & & & & & & & & \\
\hline & & $15 \mathrm{D}$ & $30 \mathrm{D}$ & $45 \mathrm{D}$ & $15 \mathrm{D}$ & $30 \mathrm{D}$ & $45 \mathrm{D}$ & $15 \mathrm{D}$ & $30 \mathrm{D}$ & $45 \mathrm{D}$ \\
\hline \multirow[t]{2}{*}{ Okha } & $\mathrm{R}_{1}$ & 20.4 & 34.2 & 60.2 & 18.6 & 32.5 & 55.3 & 12.3 & 19.5 & 33.8 \\
\hline & $\mathrm{R}_{2}$ & 21.5 & 35.0 & 62.5 & 19.5 & 31.9 & 54.2 & 11.5 & 17.8 & 32.5 \\
\hline \multirow[t]{2}{*}{ Dwarka } & $\mathrm{R}_{1}$ & 19.4 & 40.5 & 52.4 & 15.7 & 27.4 & 40.2 & 10.2 & 16.5 & 24.2 \\
\hline & $\mathrm{R}_{2}$ & 18.2 & 39.4 & 50.5 & 14.2 & 28.8 & 39.7 & 9.4 & 15.2 & 25.3 \\
\hline \multirow[t]{2}{*}{ Porbandar } & $\mathrm{R}_{1}$ & 12.3 & 19.5 & 33.8 & 9.5 & 15.3 & 21.8 & 9.2 & 15.0 & 20.4 \\
\hline & $\mathrm{R}_{2}$ & 11.5 & 17.8 & 32.5 & 10.0 & 16.4 & 22.6 & 9.0 & 15.0 & 20.0 \\
\hline \multirow[t]{2}{*}{ Chorwad } & $\mathrm{R}_{1}$ & 19.3 & 31.5 & 59.8 & 16.2 & 29.3 & 52.3 & 10.5 & 19.0 & 30.5 \\
\hline & $\mathrm{R}_{2}$ & 18.5 & 31.0 & 59.5 & 18.4 & 30.1 & 52.0 & 10.0 & 18.8 & 30.0 \\
\hline \multirow[t]{2}{*}{ Veraval } & $\mathrm{R}_{1}$ & 20.8 & 33.6 & 48.5 & 18.6 & 30.5 & 44.5 & 9.5 & 15.3 & 21.8 \\
\hline & $\mathrm{R}_{2}$ & 19.6 & 35.8 & 50.7 & 20.4 & 31.4 & 42.5 & 10.0 & 16.4 & 22.6 \\
\hline
\end{tabular}

in all stations at summer, winter and monsoon not much variation were recorded. The nitrate and total phosphorus was high in Okha area (summer 20.4 and 2.4, winter 17.56 and 1.97, monsoon 14.23 and 1.23) and lowest was recorded in Porbandar with nutrient NO3-N 11.31 (S), 8.68 (W), 8.56 (M) and total phosphate 2.4 (S), 0.84 (W), 0.74 (M).

So this study shows that Okha, Dwarka and Chorwad coastal areas are suitable for $K$. alvarezii culture in summer, winter and monsoon seasons. The most extensive growth is found in the summer season. (Table 3, 4 and 5).

Table 3: Water quality parameters in summer 15, 30 and 45 days collected surface water sample during the study period (Average summer values)

\begin{tabular}{lcccc}
\hline $\begin{array}{l}\text { Site } \\
\text { (Summer) }\end{array}$ & $\begin{array}{c}\text { W. Temp } \\
\left({ }^{\circ} \mathrm{C}\right)\end{array}$ & $\begin{array}{c}\text { Salinity } \\
\left(\mathrm{g} \mathrm{kg}^{-1}\right)\end{array}$ & $\begin{array}{c}\mathrm{NO}_{3}-\mathrm{N} \\
\left(\mu \mathrm{g} \mathrm{I}^{-1}\right)\end{array}$ & $\begin{array}{c}\text { Total P } \\
\left(\mu \mathrm{g}^{-1}\right)\end{array}$ \\
\hline Okha & 30 & 32 & 20.4 & 2.4 \\
Dwarka & 31 & 34.25 & 13.62 & 0.9 \\
Porbandar & 33 & 36.54 & 11.31 & 1.5 \\
Chorwad & 30 & 31.52 & 16.56 & 1.89 \\
Veraval & 32 & 34.56 & 14.71 & 1.57 \\
\hline
\end{tabular}

Table 4: Water quality parameters in winter 15,30 and 45 days collected surface water sample during the study period (Average winter values)

\begin{tabular}{lcccc}
\hline $\begin{array}{l}\text { Site } \\
\text { (Summer) }\end{array}$ & $\begin{array}{c}\text { W. Temp } \\
\left({ }^{\circ} \mathrm{C}\right)\end{array}$ & $\begin{array}{c}\text { Salinity } \\
\left(\mathrm{g} \mathrm{kg}^{-1}\right)\end{array}$ & $\begin{array}{c}\mathrm{NO}_{3}-\mathrm{N} \\
\left(\mu \mathrm{g} \mathrm{I}^{-1}\right)\end{array}$ & $\begin{array}{c}\text { Total P } \\
\left(\mu \mathrm{I} \mathrm{I}^{-1}\right)\end{array}$ \\
\hline Okha & 27 & 31.2 & 17.56 & 1.97 \\
Dwarka & 28 & 33.5 & 10.57 & 1.23 \\
Porbandar & 29 & 35.2 & 8.68 & 0.84 \\
Chorwad & 28 & 31.7 & 15.40 & 1.28 \\
Veraval & 30 & 33.4 & 13.87 & 2.25 \\
\hline
\end{tabular}

Table 5: Water quality parameters in monsoon 15, 30 and 45 days collected surface water sample during the study period (Average winter values)

\begin{tabular}{lcccc}
\hline $\begin{array}{l}\text { Site } \\
\text { Summer })\end{array}$ & $\begin{array}{c}\text { W. Temp } \\
\left({ }^{\circ} \mathrm{C}\right)\end{array}$ & $\begin{array}{c}\text { Salinity } \\
\left(\mathrm{g} \mathrm{kg}^{-1}\right)\end{array}$ & $\begin{array}{c}\mathrm{NO}_{3}-\mathrm{N} \\
\left(\mu \mathrm{g} \mathrm{I}^{-1}\right)\end{array}$ & $\begin{array}{c}\text { Total P } \\
\left(\mu \mathrm{g} \mathrm{l}^{-1}\right)\end{array}$ \\
\hline Okha & 26 & 32.1 & 14.23 & 1.23 \\
Dwarka & 26.3 & 31.5 & 10.55 & 0.98 \\
Porbandar & 27.4 & 31.8 & 8.56 & 0.74 \\
Chorwad & 27 & 32.8 & 15.74 & 1.02 \\
Veraval & 28 & 33.4 & 13.21 & 1.24 \\
\hline
\end{tabular}

\section{Conclusion}

Successful of commercial cultivation of $K$. alvarezii has shown that scientific innovations can benefit coastal rural populations which lack alternative economic opportunities. The continued advancement in both farming methods as well as integrated product development is crucial for attracting business entrepreneurs. The rural economy not only will be boosted though commercial seaweed cultivation but also by employing liquid and solid fertilizers produced from the algal biomass.

\section{Reference}

Bixler, H.J., Porse, H., 2011. A decade of change in the seaweed hydrocolloids industry. Journal of Applied Phycology 23(3), 321-335.

Chandrasekaran, S., Nagendran, N.A., Pandiaraja, D., Krishnankutty, N., Kamalakannan, B., 2008. Bioinvasion of Kappaphycus alvarezii on corals in the Gulf of Mannar, India. Current Science 94, 1167-1172.

C.M.F.R.I., 2015. Annual Report 2014-2015, Mariculture: Trial on Integrated Multi Trophic Aquaculture (IMTA) in a participatory mode, Kochi, India, 219. 
Dawes, C.J., Lluisma, A.O., Trono, G.C., 1994. Laboratory and field growth studies of commercial strains of Eucheuma denticulatum and Kappaphycus alvarezii in the Philippines. Journal of Applied Phycology 6, 2124.

De Goes, H.G., Reis, R.P., 2011. An initial comparison of tubular netting versus tie-tie methods of cultivation for Kappaphycus alvarezii (Rhodophyta, Solieriaceae) on the south coast of Rio de Janeiro State, Brazil. Journal of Applied Phycology 23, 607-613.

Ghosh, P.K., Ghosh, A., Mondal, D., Prasad, K., Agarwal, P.K., Agarwal, P., Zodape, S.T., Vijay Anand, K.G., 2014. Gibberellic acid (GA3) free Kappaphycus alvarezii sap and its application thereof. PCT patent application 14, $783 / 980$.

Makwana, N.P., 2011. Growth comparison of the seaweed Kappaphycus alvarezii in nine different coastal areas of Gujarat coast, India. Advances in Applied Science Research 2(3), 99-106.

Mantri, V.A., Eswaran, K., Shanmugam, M., Ganesan, M., Veeragurunathan, V., Thiruppathi, S., Seth, A., 2017. An appraisal on commercial farming of Kappaphycus alvarezii in India: success in diversification of livelihood and prospects. Journal of Applied Phycology 29(1), 335-357.
Monica, G. K., Nived Sreenadhan, Singh, V.V. 2016. Cultivation of Kappaphycus alvarezii (Doty) Doty ex P. C. Silva along the coast of Palshet, Guhagar, Maharashtra. Indian Journal of GeoMarine Science 45(5), 666-670.

Naguit, M.R.A., Tisera, W.L., Laniosa, A., 2009. Growth performance and carrageenan yield of Kappaphycus alvarezii (Doty) and Eucheuma denticulatum (Burman) Collins Et Harvey, Farmed in Bais Bay, Negros Oriental and Olingan, Dipolog City. The Threshold, 4, 3851.

Necas, J., Bartosikova, L., 2013. Carrageenan a review. Vet Med-Czech 58, 187-205.

Khambhaty, Y., Mody, K., Gandhi, M.R., Thampy, S., Maiti, P., Brahmbhatt, H., Ghosh, P.K., 2012. Kappaphycus alvarezii as a source of bioethanol. Bioresource technology 103(1), 180-185.

Renuga, G., Osman, A., Thandapani, B.A., 2013. Evaluation of marine algae Kappaphycus alvarezii as a source of natural preservative ingredient. International Journal of Pharmaceutical Science and Research, 4, 3548-3555.

Thirumaran, G., Anantharaman, P., 2009. Daily Growth Rate of Field Farming Seaweed Kappaphycus alvarezii (Doty) Doty ex. P. Silva in Vellar Estuary. World Journal of Fish and Marine Sciences 1(3), 144-153. 